chronic chills, chronic congestion of the larynx, consumption, cough, convalescence, debility, diptheria, dyspnoea, dyspepsia, distrophia, glandular disorders, hæmorrhage, indigestion, insomnia, melancholia, menorrhagia, nervous affections, nervous system, neuralgia, night sweats, ocular paralysis, panphobia, ozena, paralysis, incipient phthisis, pneumonia, rapid growth, rickets, scrofulous diseases, skin diseases, strumous diseases and strumous keratitis, whooping cough, epilepsy, diarrhcea, incontinence of urine, paralysis agitans (Parkinson's disease, I suppose is intended, as there is in this disease no paralysis) leucorrhoea, marasmus, sleeplessness, loss of memory, loss of voice, timidity, despondency, hysteria, hypochrondria, wheezing, difficult or painful parturition, and change of life.

The medical press is loaded with tirades against admitting the non-educated into the profession, and yet the recommendations of this "Syrup" "are signed by the best-educated physicians who have ever been produced in the whole civilized world.

This wholesale cure-all reminds me of a little story illustrative of some people's estimate of the action of remedies.

While a student of medicine under the late Dr. F. R. Payne, of Illinois, his friend, Dr. Johnson, came into my preceptor's office, and each related the greatest medical events of their long, large and successful practice. Dr. Johrison was a graduate of the old Jefferson Medical College of Philadelphia; was surgeon in the war of 1812 ; had treated nearly every medical and surgical trouble to which human flesh is heir, and in a large practice of over half a century, the events wherein his fees and eclat exceeded all the other achievements of his active medical life, were, rubbing a little sweet oil upon a child, which, while returning to his office, he saw playing in some smartweed near one of those large suburban residences near Philadelphia, to which he was subsequently called. The other, and possibly the greater, measured by the scale of dollars and honors, was wherein he was called a long distance to consult with a number of talented physicians in regard to a lady's health. As he and the other physicians were going from the bedside to a room where they might not be overheard in their sapient deductions, they passed through the diningroom, and as he passed, he picked up a piece of biscuit, which during the consultation he rolled into pills. At the end of a long and very learned history, diagnosis, prognosis and treatment of the case, he said, reaching out his hand containing the bread pills, "Gentlemen, I would give her one of these pills every third hour," which they did, without questioning as to their contents. It is needless to say the lady recovered (and a few years subsequently, was delivered of triplets.) This treatment is in keeping with the diversity and multiplicity of diseases for which these two-possibly most excellent syrup and elixir-are given, but the absurdity of any two remedies filling the requirements set forth by their respective proprietors-although thoroughly sustained by many physicians-is, to say the least, immense.

Our patrons, finding our prescriptions headed by never so reliable a drug firm's name, soon come to the conclusion that other people furnish us not only medicines, but also the brains to use them, and they say, why not get Mrs. Winslow's Soothing-Syrup; Dr. Hayhirst's Wild-Cat Liniment-as well do so as that their doctor should prescribe Fellow's, Tilden's, or anybody else's remedies.

There is a too successful eftort being made by the leading drug houses to control., forestall, abridge, and render subservient to drug circles the whole medical profession. This is being effected by producing ready prepared compounds, not strictly patent medicines, yet answering the same purpose, for the dose and the diseases for which physicians must prescribe them is fully delineated on wrapper and pamphlet. As a sample of this, I have cited from two sample drug firms, who have lately supremely honored your scribe by sending him full instructions what to prescribe, without the trouble of consulting Stillé, Wood, Bartholow, Headland, and a host of other writers whom we once thought knew the action of medicines. The effect, both moral and medical, produced by this purchase of surnamed remedies, is injurious to the pocket and status of the practitioner, particularly if he be a neophite, for be it known the druggist who sells these proprietary preparations is much more liable to depreciate the merits of the prescriber, than if the dispenser's own pharmaceutical drugs were ordered. Besides this, no known remedy or combination of remedies will cure the list of diseases for which these drug firms have physicians' certificates as to the efficacy of their compounds. The trouble lies within the profession. They are owned by the druggists, and do not dare refuse certificates for fear of loss of influence.

In conclusion, I will ask the profession what is the necessity for studentsattending medical colleges, purchasing microscopes, and studying Koch's bacilli tuberculi, baccillivariolii, et hoc gemus omni-when all they have to do in any disease is to get an almanac or one of these gratuitous pamphlets, printed solely for their professional benefit, wherein they will find more remedial expedients than were known to Hippocrates, Assculapius, Sydenham, and their followers all.

Evansville, Ind.

George R. Center, m.D., m.A.

\section{THE MICHIGAN MEDICAL REGISTRATION LAW.}

This law is now in full force. Since the days of Solon down to the present time, it would be difficult to discover another piece of legislation equal to it in stupidity and uselessness. It would not be unreasonable to suppose, that the framer of this law had just emerged from the midnight of the Dark Ages in the form of a medical Rip Van Winkle, and through the thin mist of his recently acquired vision, saw the apparent dangerous conditicn of his professional brethren, as well as his constituents ; then, after due deliberation, resolved to redeem the State from quack. ery, and thereby become a public benefactor in his day. But the reverse is the case.

The miserable charlatan, ignorant of anatomy and physiology ; ignorant of every scientific fact in relation to the human system ; destitute of every professional qualification, is a legal practitioner of medicine. 
Men who cannot read three lines correctly in any scientific work; who have never dissected; who have never made a post-mortem examination of a body, with the exception of the pig; and then only to slice up the animal and devour him like a cormorant, are paraded before the public as legal physicians. These parasites of a noble art find their names published side by side with men of acknowledged skill and ability ; men who have spent half a century in the profession, and who now for the first time witness their names in the same category with the most unscrupulous mountebank, " the steam doctor," and a list of ignoramuses whom this State has legalized as practitioners of medicine and surgery.

A law regulating the practice of medicine so broad that men without the slightest claim to medical knowledge; men whose only claim to medical education is that they have "practiced common sense for thirty years," or that they have put up a few congh mixtures, or a clap mixture for some gullible young man, but without sufficient ability to compound prescriptions properly, are now registered as physicians in the State of Michigan.

Such a specimen of medical legislation would doubtless do honor to the King of Dahomey; but to the State of Michigan it must ever remain an insult on her intelligence until repealed. The people are not benefited by it ; scientific medicine certainly is not. The legislative body that passed this law, and the Governor who did not veto the bill, must ever look upon it as one of the most pusillanimous products of their puerile legislation.

Tecumseb, Mich.

$$
\text { J. F. JEnkins, M.D. }
$$

\section{MISCELLANEOUS.}

A Female Government Vaccinator.-Mrs. Annie Jessie Chambers has been appointed public vaccinator for the district of Morgan, South Australia.

Official List of Changes in the Stations and Duties of Officers Serving in the Medical Department United States Army, from DecemBER 28, I883, TO JANUARY 4, I884.

Appel, Daniel M., Captain and Assistant Surgeon, having relinquished the unexpired portion of leave of absence granted by S. O. 68, Headquarters Division of the Atlantic, November 16,1883 , and reported for assignment, assigned to cluty at Fort Porter, N. Y. (Par. 2, S. O. 247, Department of the East, December 29, I883).

Ijist of Changes in the Medical Corps of the Navy During Week ending: Januari 5, 1884.

Medical Inspector, A. Hudson, from duty as Assistant to the Bureau of Medicine and Surgery, on the 18 th inst., to the U. S. S. Lancaster, as the relief of Medical Inspector N. L. Bates, who is to be detached and ordered home.

P. A. Surgeon A. C. H. Russell, from the Navy Yard, Washington, to hold himself in readiness for sea service.

\section{NEW BOOKS.}

Altvater, Paul. Die Morphium-Einspritzungen. 8vo., 62 pp., 3. Aufl, Neuwied, Heuser.

Ammon, F. A. V. Die ersten Mutterpflichten und die ersten Kindespflege. 26. Aufl, 8vo, XVI, 315 pp. l,eipzig.

Anweisung zur Ausführung der Desinfection für gepruifte Heildiener und für sonst amtlich in der I)esinfection beauftragie l'ersonen. Svo., I6 pp. Berlin, Hayn's Erben.

Aufrecht, Oberarzt Dr. Pathologische Mitteilungen. 2. Heft, 8 vo , III, 92 pp.. Magdeburg, Faber.

Bergmann, Ernst $V$ Die Schicksale der 'Transfusion im letzen Decennium. 8vo., 3I pp. Berlin, Hirschwald.

Bolz, Hans. Beiträge zur Gasuistik der Nephrectomie. Inaugural I Dissertation. 8vo., $93 \mathrm{pp}$. Dorpat, Schnakenburg.

Bricke, Frnst. Vorlesungen über Physiologie. 3 Auf. Mit I') 1 Iolyschnitte, 8vo., IV, 355 pp. Wien, Braumitller.

Elsstein, 1)r. Wilh. Die Fettleibigkeit (Corpulenz) und ihre Behandlung nach physiologischen Grundsätzen. 6. Aufl., 8vo., VI, $5^{6} \mathrm{pp}$. Wiesbaden, Bergmann.

Ziegler, Dr. Einst. Lehrbuch der allgemeinen und speciellen pathologischen Anatomie und Pathogenese. 2. Theil, 3. Abth., 8vo. Jena, Fischer.

7uelzer, 1). W. Untersuchungen ïber die Semiologie des Harns, 8vo, VII, I66 pp. Berlin, Hempel.

Brown, I. (i. Medical I)iagnosis: A Manual of Clinical Methods. 2nd edit., 8vo. Edinburgh, Bell \& Bro. 370 pp., ros. $6 \mathrm{~d}$

Clarke, W. B., and Lockwood, C. B. The Dissectors' Manual. 49 engravings, 12 mo., $390 \mathrm{pp}$. London, Cassell. $6 \mathrm{~s}$.

Drummond, I). Diseases of the Brain and Spinal Cord, a Guide to their Pathology. 8vo. London, Kimpton. Ios. 6d

Gant, F. J. Diseases of the Bladder, Prostate Gland, and Urethra. 5th ed., illus, London, Baillière. I 2s. 6rl.

History of the Society for the Abolition of Vivisection. London, Pickering. Is.

Mann, E. C. A Manual of Psychological Medicine and Allied Nerrous Diseases, etc. 8vo., 714 pp. London, Churchill. 24 s.

Porritt, N. The Operative Treatment of Intra-Thoracic Effusion. 8 vo., $288 \mathrm{pp}$. London, Churchill. $6 \mathrm{~s}$.

Students Guide to the Examinations of Apothecaries Hall. I 2 mo. london, Kimpton Is.

Thudichum, J I.. W. On Polypus in the Nose, and other Affections of the Nasal Cavity. 3d edit., 8vo. Jondon, Bailliére. Is.

Auerbach, Dr. H. I Loranicum, ein neues Mittel gegen einige gefährliche Krankheiten des Verdauungsweges. 8vo., I I pp. Berlin.

Capellmam, Dr. C. Facultative Sterilität ohne Verletzung der Sittengesetze. 8vo., 2 I pp. Aachen.

Leisnick. H., Mielck, W. H, und Korach, S. Der TorfmoosVerband. Mit 3 Abbildungen, 8vo., $42 \mathrm{pp}$. Hamburg.

Lexikon, biographisches, der hervorragenden Aerzte aller Zeiten und Völker. In ca. 4 Bänden. I. Lieferung, 8 vo. Wien.

Lorenz, Dr. Adf. Die Lehre vom erworbenen Plattfusse. Mit 8 I ith. Taf, 8vo, IV, 97 pp. Stuttgart.

Purjesz, Dr. Ign. Therapeutisches Recept-Taschenbuch für venerische Krankheiten. 8vo, VIII, 96 pp. Stuttgart.

Real-Encyclopädie der gesammten Heilkuncle. MedicinischChirurgisches Hand wörterbuch für praktische Aerzte. Schluss. Heft. Wien.

Medical Ethics and Medical Etiquette, by Drs. Post, Ely, Vanderpoel, Pitcher, Hun, Wey, Agnew, Jacobi and others. New York, G. P. Putnams' Sons. I 2 mo., cl., \$1.25.

Mulheron, J. J. The Collective Investigation of Diphtheria. Detroit, Mich. 8vo., I $20 \mathrm{pp}, \mathrm{cl}$., \$I,00. 